\title{
Basin development and tectonic history of the Middle Magdalena Valley
}

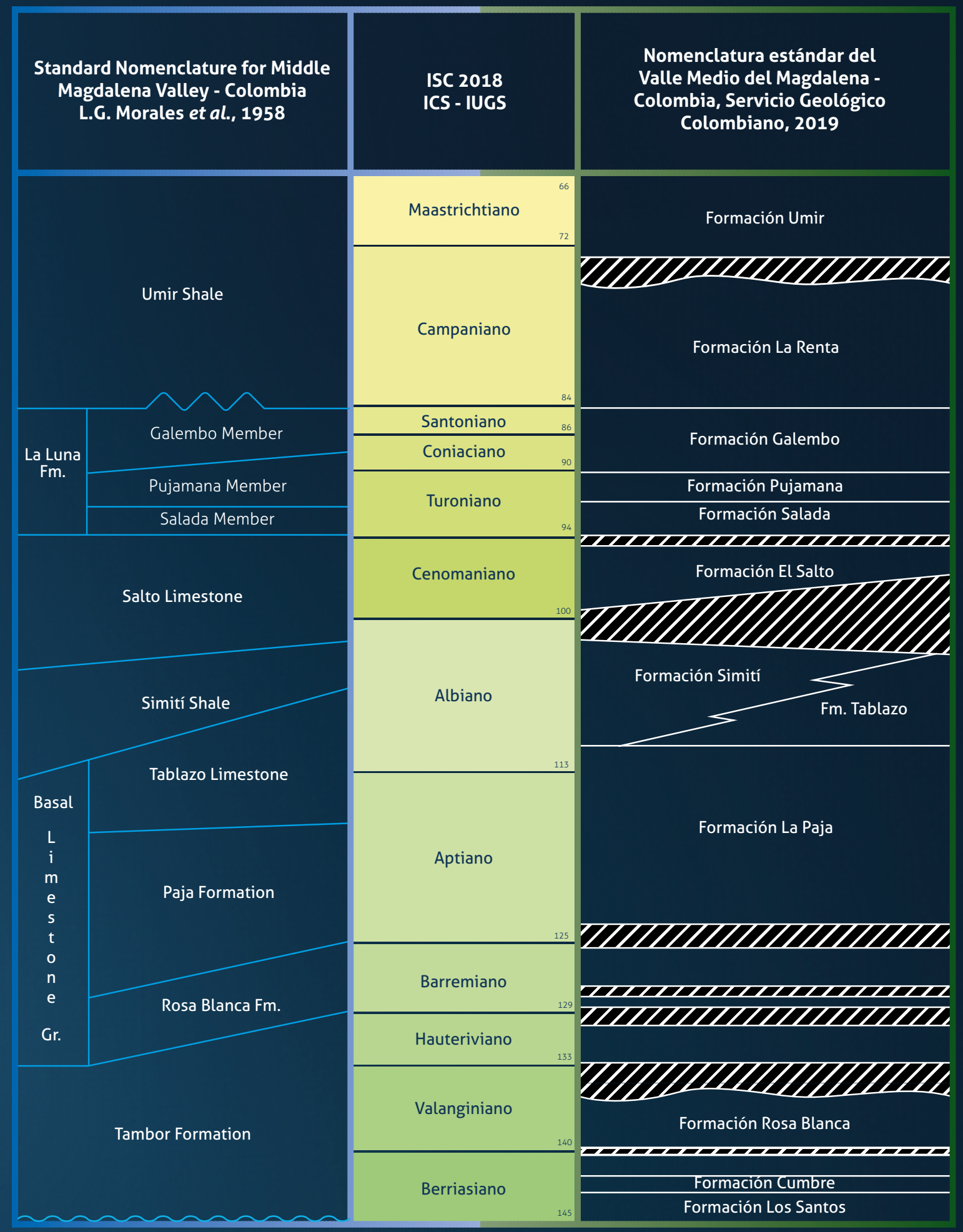

"Howewer, as our studies continue, more and more concealed breaks become apparent" 
Portadilla: Standard nomenclature for the Middle Magdalena Valley adopted by the Servicio Geológico Colombiano.

Citación Etayo-Serna, Fernando. 2019. "Basin development and tectonic history of the Middle Magdalena Valley". En Estudios geológicos y paleontológicos sobre el Cretácico en la región del embalse del río Sogamoso, Valle Medio del Magdalena, dirección científica y edición de Fernando Etayo-Serna. Compilación de los Estudios Geológicos Oficiales en Colombia vol. XXIII. Bogotá: Servicio Geológico Colombiano. 


\section{Basin development and tectonic history of the Middle Magdalena Valley}

Fernando Etayo-Serna

Hans Stille's work initiated tectonic studies in the Middle Magdalena Valley and introduced the word graben (Hubach 1929). Years later, Harrison wrote: "The Upper Magdalena Valley is a trough like depression or Graben (1930, 399. Notice the equivocal Upper) [...] that if could be flooded [...]would recall the northern end of the Red Sea". According to Harrison, this "trench [...] broke down in early Tertiary times" (op. cit., 408). Likewise, pre-Paleozoic and Paleozoic rocks of Colombia were named basement, while cover was used for rocks of Mesozoic to Pleistocene age (Hubach 1929, after Stille 1907). The acceptance of a Tertiary age for the MMV led to the adoption of Dana's geosynclinal terminology to name the space of deposition of Cretaceous sediments in the MMV (Hubach 1929; Cizancourt 1933; Morales and The Colombian Petroleum Industry 1958; Bürgl 1961; Julivert 1961).

A thorough analysis of the distribution of Cretaceous sedimentary rocks in Colombia (Etayo, Renzoni and Barrero 1969, 1976) showed that these rocks did not fit a geosynclinal outline. Fabre (1983) reintroduced the idea of a graben, adding that it was active since the Early Cretaceous, and renamed it the Magdalena-Tablazo Basin.

Inasmuch as Harrison's paper was included in Section VI-Rift Valleys of the 15th International Geological Congress in Pretoria, terms such as Edward Suess's graben and J. W. Gregory's rift (Willis 1928) become almost synonymous and commutative in the geological literature on Colombia (Sarmiento Rojas 2001; Toro et al. 2002; Rolón 2004; Barrero et al. 2007).

\section{OVERVIEW OF THE CRETACEOUS IN THE MIDDLE MAGDALENA VALLEY}

The Río Magdalena basin consists of three geomorphically distinct sectors, each with a different geological history: (1) the south sector or Upper Magdalena Valley, extending from the riverhead to Honda, occupies the axial domain of a Mesozoic back-arc; (2) the middle sector or Middle Magdalena Valley, extends from Honda to El Banco and occupies the Mesozoic rifted central part of Colombia; and (3) the northeast lower sector, the Lower Magdalena Valley, goes from El Banco to Barranquilla and developed over a "triangular transtensional basin" (Barrero et al. 2007) of late Cenozoic age (Cáceres, Cediel and Etayo-Serna 2003) (fig. 1).

The tectonic framework of the MMV basement intermittently affected its stratigraphic architecture. More field information is necessary to validate modern speculations not based on any direct observation and at the same time, as advised by J. T. Wilson (1990), we should not permit "Neglect of what is already known".

\section{INTERPLAY OF TECTONISM AND SEA LEVEL CHANGES IN THE MMV DURING THE CRETACEOUS}

In a plate tectonic setting, the Middle Magdalena Valley was generated during the "extensional stage" of a Late Triassic to Jurassic rifting episode that affected northwestern South América (Cáceres, Cediel and Etayo-Serna 2003) (fig. 1). The original structure of the MMV is that of an asymmetric rift that progressively slants to the west. Proximity to the faulted and raised block of the Santander Massif has caused up and down movements of basement blocks like piano keys, which caused the following features. 1) An angular unconformity between Cretaceous Los Santos and Jurassic Jordán Formations (Notestein in Schuchert 1935; Julivert and Téllez 1963; Cediel 1968; Laverde 1995; Rolón and Carrero 1995) (fig. 2A). 2) A disconformity between the lower upper Valanginian Carrizal Member and the lower Hauterivian Zo Member of the Rosa Blanca Formation (fig. 2B). 3) Condensation of middle Barremian beds and a paraconformity between these and the upper lower Aptian beds of the La Paja Formation (Gaona, Maurrasse and Etayo-Serna 2013) (fig. 2D). 4) A paraconformity between the cuspidal beds of the Rosa Blanca Formation and basal upper lower Barremian beds of the La Paja Formation (fig. 2C). 5) Prograding and retrograding sequences in the upper beds of the Tablazo Formation (fig. 3). 6) A composite hardground surface at the top of the Tablazo Formation, upper lower Albian (fig. 2E). 7) Beveled contact between the Simití and El Salto Formations.

It has been demonstrated that "Compressional tectonics [...] controlled the stratigraphic and structural attributes of the southern Middle Magdalena Valley Basin since 70 Ma" (Gómez et al. 2003, 146). 


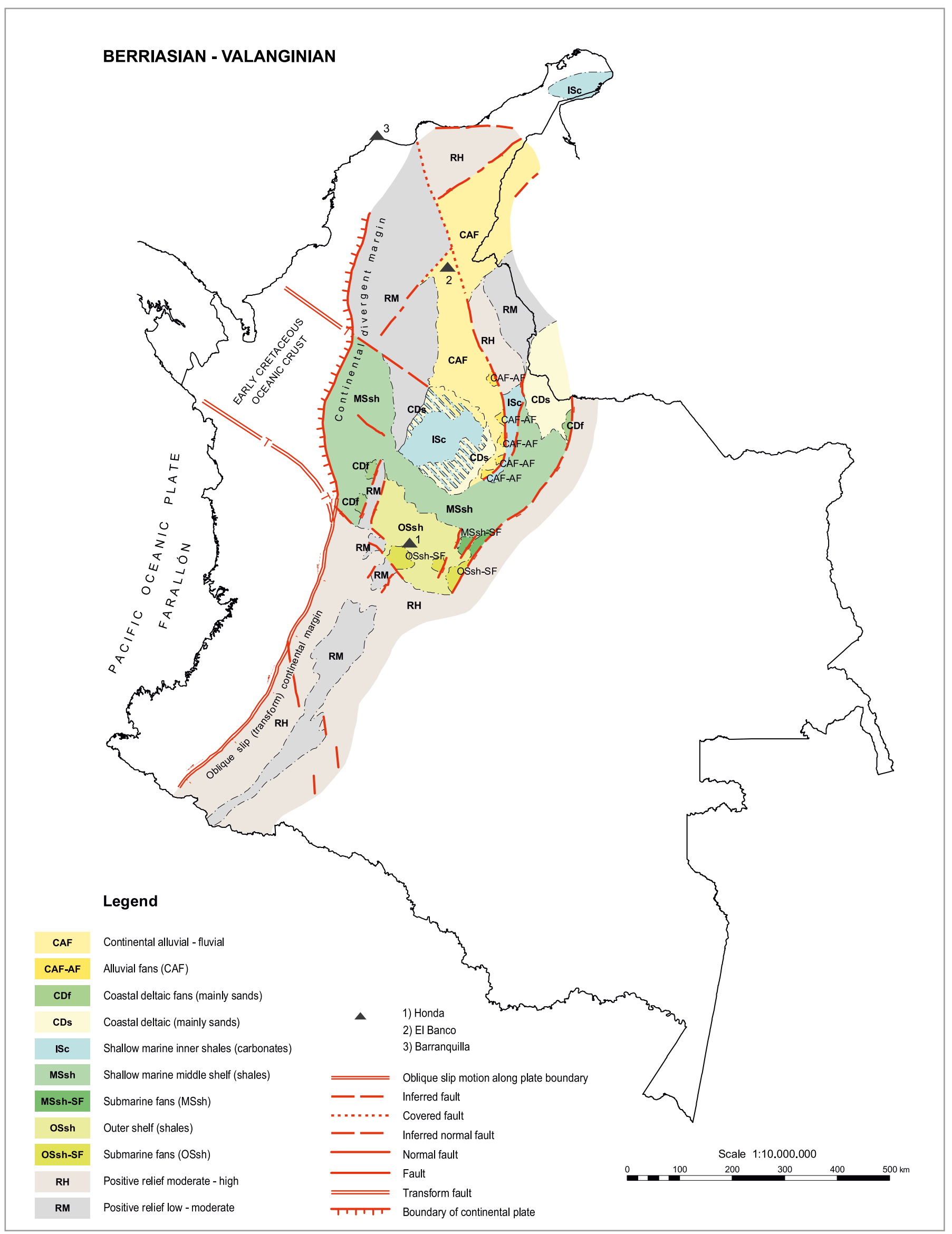

Figure 1. Taken from: Facies distribution and tectonic setting through the Phanerozoic of Colombia (Cáceres, Cediel and Etayo-Serna 2003). 


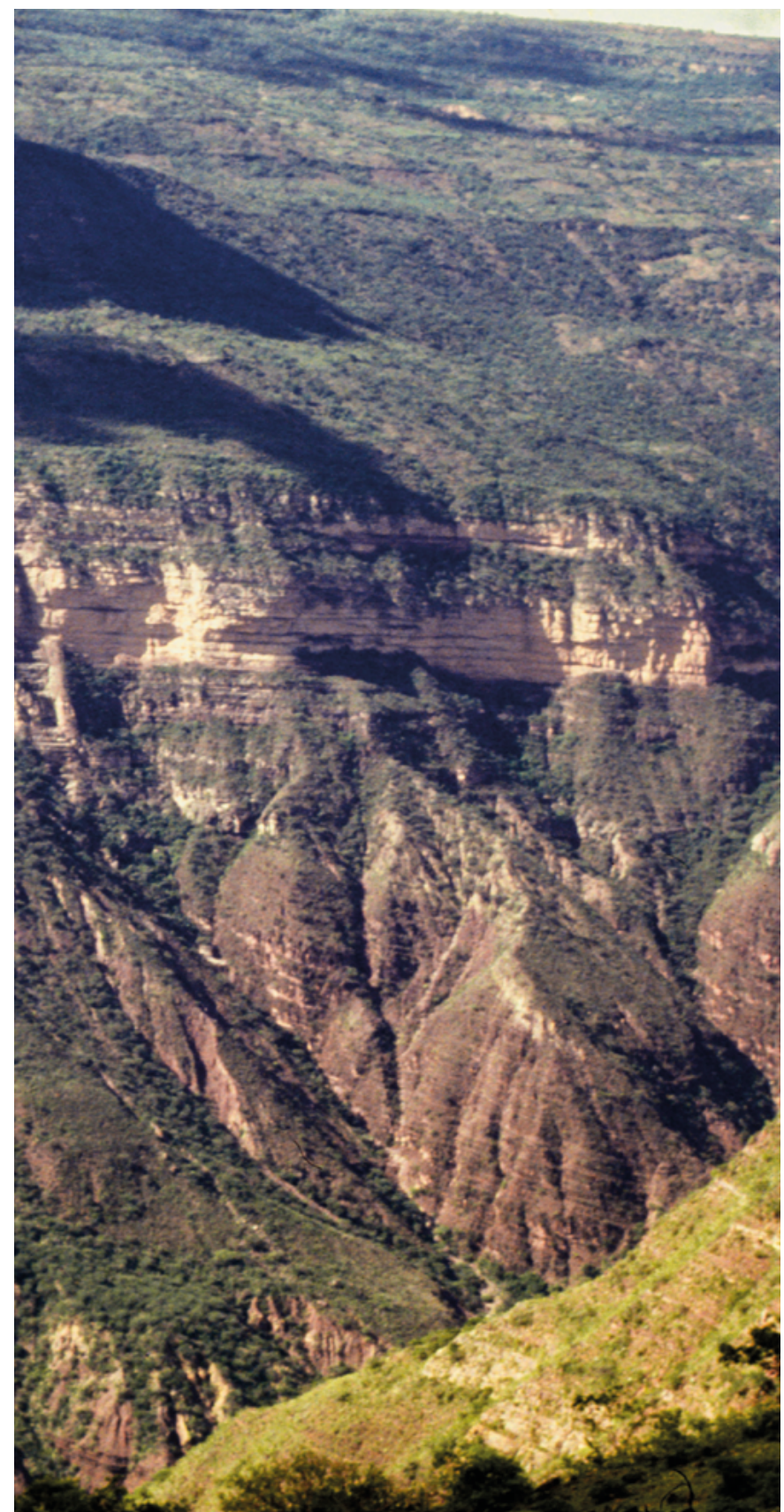

Figure 2A. Angular unconformity between moderately dipping Jordán Formation beds and horizontal Los Santos Formation. Photo taken from N scarp of the Chicamocha River, Camino del Roto, looking SE. (see fig. 4). Photo by F. Etayo-Serna.

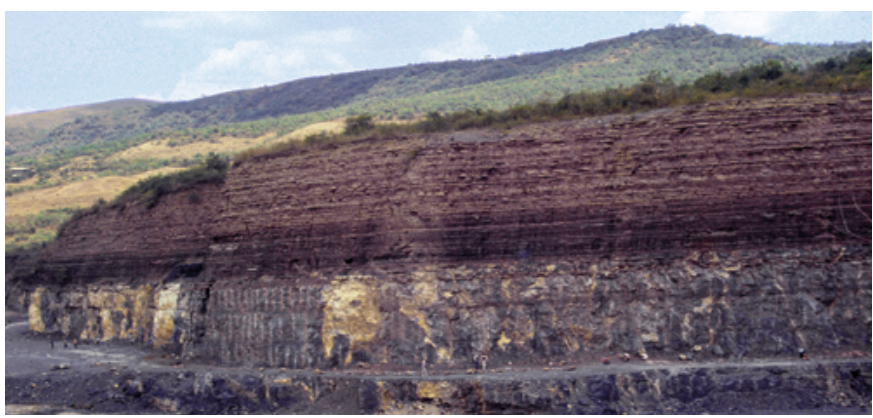

Figure 2C. Paraconformity between medial beds of the La Paja Formation (organic-rich marlstone, calcareous clay shales and clay shales) of upper lower Aptian age overlying condensed middle Barremian wackestone, Curití Quarry. Photo by F. Etayo-Serna (Gaona, Maurrasse and Etayo-Serna 2013).

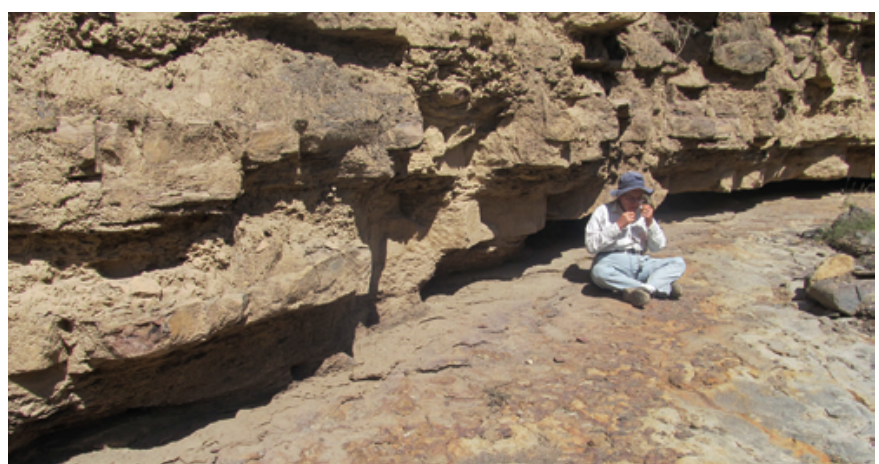

Figure 2D. Paraconformity between cuspidal beds of the Rosa Blanca Formation and basal beds of the La Paja Formation. Private road from Los Santos to El Carrancho gypsum mine. Photo by D. Montoya (see D. Montoya 2019a).

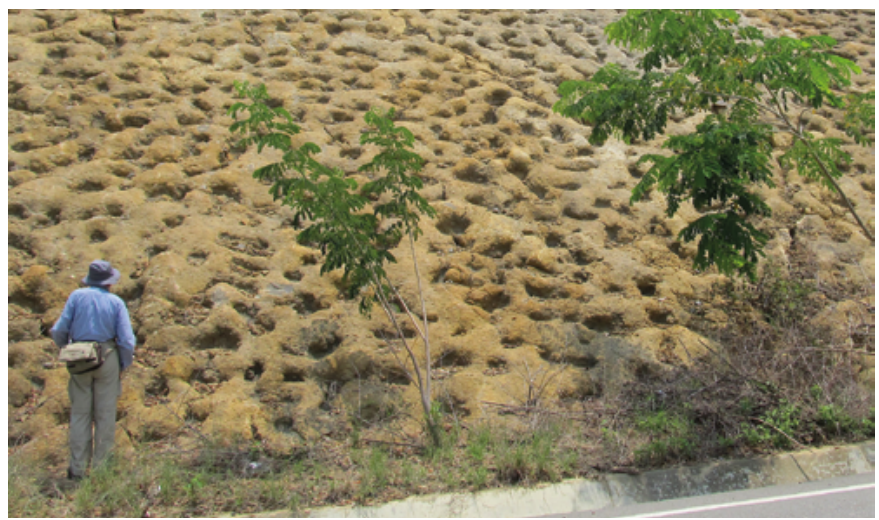

Figure 2E. Composite hardground surface at top of the Tablazo Formation. Eastern side of Lebrija-San Vicente de Chucurí road, near the bridge over the Sogamoso River (N: $1.269 .645^{\circ}, \mathrm{E}: 1.081 .053^{\circ}, \mathrm{Z}: 352 \mathrm{~m}$ ). Photo by D. Montoya (see Montoya 2019b; Immenhauser et al. 2000, fig. 11).

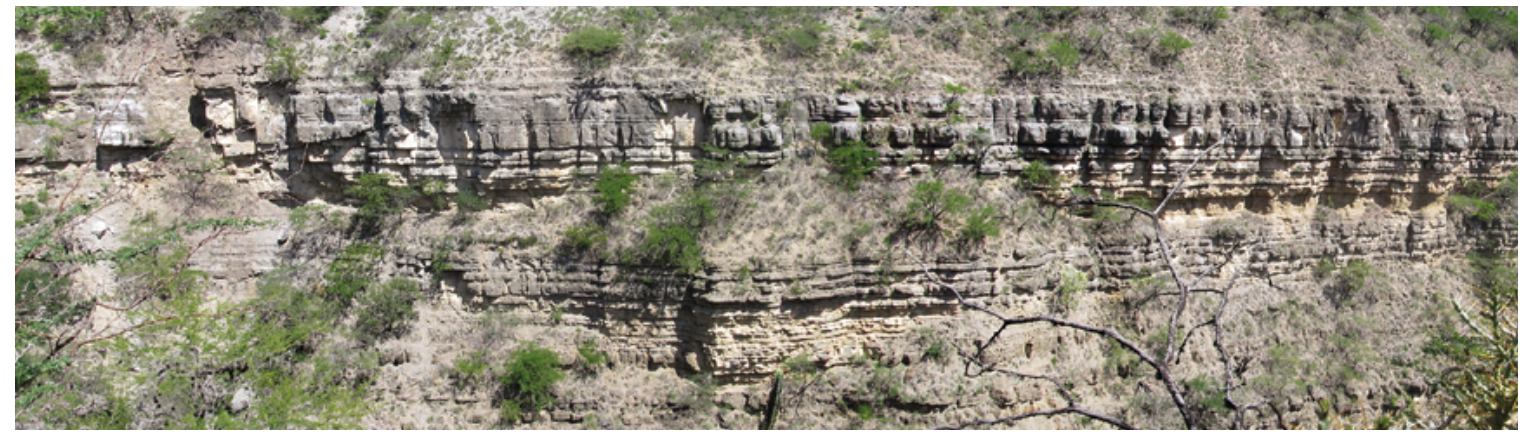

Figure 2B. Disconformity between the upper beds of the Carrizal Member, slightly bent, and bed $\mathrm{P}$ at the base of the Zo Member, both of the Rosa Blanca Formation. W side of El Platanalito Creek near its confluence with the Sogamoso River. Photo by D. Montoya (EtayoSerna and Guzmán Ospitia 2019). 


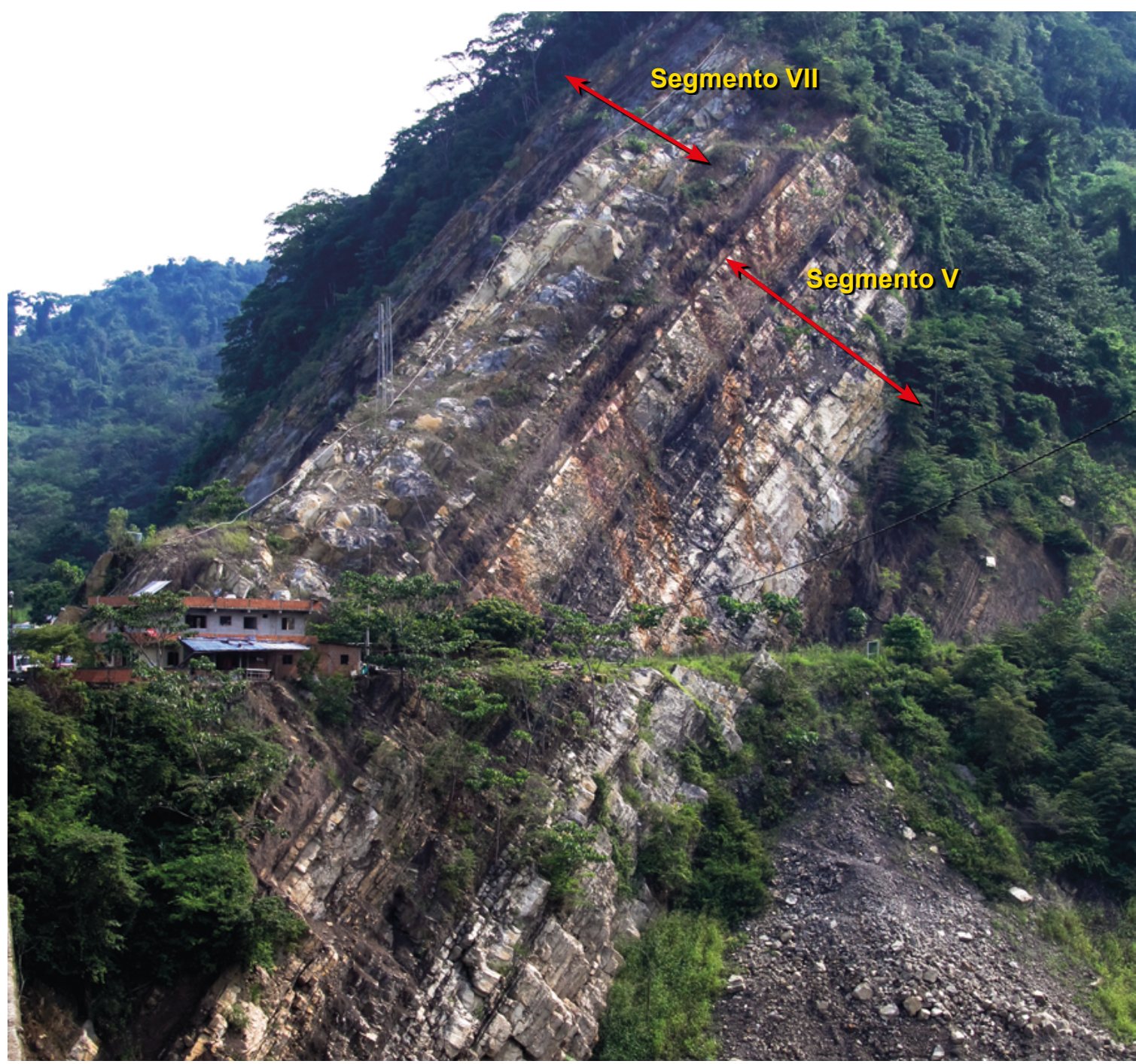

Figure 3A. View of segments VII to V of the Tablazo Formation. A cliff section at the junction of the highway to San Vicente de Chucurri and the road to Betulia (Estadero El Nuevo Ramo, km 22+200). Photography by D. Montoya, taken from the southern end of the bridge over Quebrada El Ramo. Notice the increase in bed thickness downdip in a fan-like arrangement from the top of the hill toward the river level.

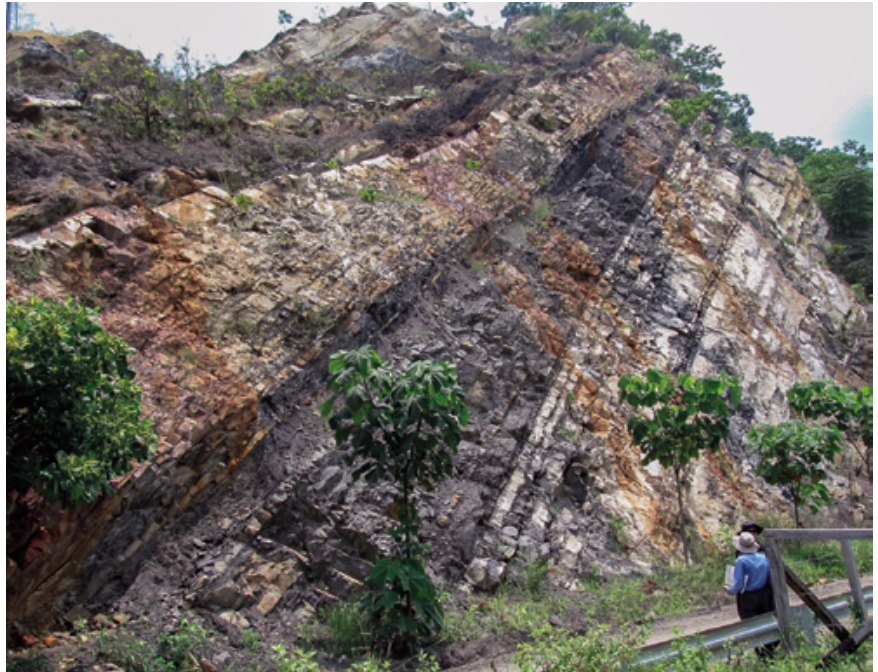

Figure 3B. Oblique close-up picture to show the internal stratification of segment $V$ of the Tablazo Formation. Observe the primary inclination of the bedding: sediments accumulated on a tilted bottom reflecting some significant tectonic episode, as demonstrated by the truncation at the top of both sets of beds (Ravnås and Steel 1998, fig. 2). Roadside outcrop in front of Estadero El Nuevo Ramo.

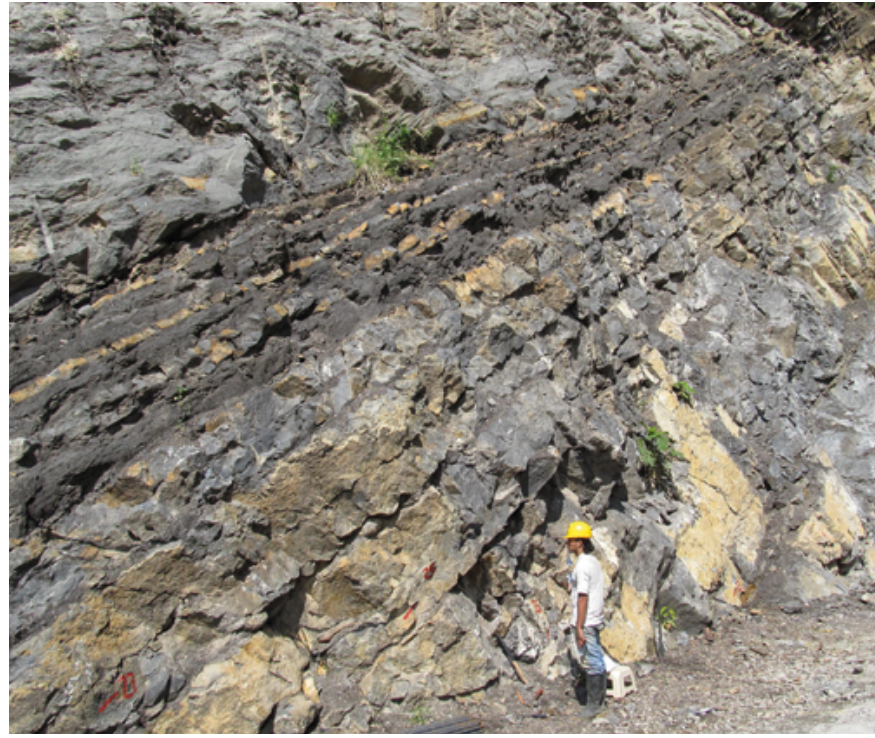

Figure 3C. Outcrop of stratigraphic segment $\mathrm{V}$ (conjunto N2 -dark- and conjunto $\mathrm{O}$-light-) of the Tablazo Formation to show the fan-shaped arrangement of beds. Cerro El Tablazo (D. Montoya, this book 2019b, fig. 90A). 
Global sea level rises seem reflected in the MMV stratigraphic sequence by the occurrence of Mediterranean short-lived ammonites of the early late Valanginian Saynoceras verrucosum (ORBIGNY, 1841), the late early Barremian Nicklesia pulchella (ORBIGNY, 1841) and Parasaynoceras horridum (ORBIGNY, 1850) (Etayo-Serna 1993; 2019), and the early middle Albian Oxytropidoceras (Mirapelia) mirapelianum (ORBIGNY, 1850) (Orbigny, 1842; Rawson 1993; Etayo-Serna 1993). It must be said here that oceanic surface waters (Tethyan) were circulating from $E$ to $W$ in the Early Cretaceous (Luyendyk, Forsyth and Phillips 1972; Etayo-Serna 1983).

\section{THE MAPPABLE LITHOLOGIC UNITS AND THE GEOLOGICAL HISTORY OF THE MMV}

The earliest Cretaceous lithostratigraphic unit recorded in the Hidrosogamoso region (figs. 2A and $\mathbf{4}$ ) is represented by the continental siliciclastic Los Santos Formation (1) (Cediel 1968; Etayo-Serna and Rodríguez 1985). Immediately above follows the transitional Cumbre Formation (2), from which diverse palynomorphs have been recovered at quebrada Aguablanca (zanjón Aguas Gordas): Inaperturopollenites sp., Araucariacites $s p$., Classopollis sp. (probably Corollina ecopetrolis Olivella), Ephedripites sp. and the spore Cyathidites sp. (D. Pons in EtayoSerna 1989). Outcrops of the Cumbre Formation on the road to Platanalito gypsum mine yields shark teeth and bivalves similar to those of the Batá Formation (Etayo-Serna et al. 2003).

In ascending order above the Cumbre, the Rosa Blanca Formation (3) initiates with the Lagunetas Member (new), which shows an $E$ to W change from sabkha deposits (supratidal) to stromatolitic limestone (subtidal); $80 \mathrm{~m}$. The age of the Los Santos and Cumbre Formations and the Lagunetas Member, based on Walter's principle of contiguity of facies, is considered Berriasian.

Sealing an erosional scar, the oolitic calcareous basal bed of the Carrizal Member (new) follows, composed of conspicuous Thalassinoides beds and decimetric wackestone beds in alternation with calcareous mudstone; $110 \mathrm{~m}$. The age of this member ranges from lower Valanginia to upper Valanginian, pars. Above the Carrizal Member in disconformable contact follows the Zo Member (new), composed of pluridecimetric cross-bedded packstone and wackestone that alternate with terrigenous mudstone; the occurrence of benthonic foraminifera is noticeable; $40 \mathrm{~m}$.

In a rapid transition follows the El Sapo Member (new), composed of conspicuous Thalassinoides beds and decimetric wackestone in alternation with terrigenous calcareous mudstone; $80 \mathrm{~m}$.

The upper part of the Rosa Blanca Formation is represented by the Zapatoca Member (new), composed of ferruginous metric sandstones in the lower part; $35 \mathrm{~m}$, and wackestone and packstone of bivalves at the top; $25 \mathrm{~m}$.

Members Zo, El Sapo and Zapatoca are dated Lower Hauterivian (Etayo Serna and Guzmán 0spitia 2019).
At the type section, the La Paja Formation (4), 290 m, is characterized by the alternation of dark calcareous and argillaceous mudstones. In segment I, calcareous mudstones are predominant, with organic matter and abundant Dasycladacean algae remains. Segment II has similar lithology but shows lenses of fibrous calcite and abundant gypsum lenses and veins. Segment III consists of predominantly argillaceous mudstones with organic matter. Segment IV comprises tabular thick-bedded calcareous mudstone (bindstones) interbedded with metric argillaceous mudstones. Segment $V$ is composed of argillaceous mudstones with organic matter and conspicuous recrystallized bindstones toward its upper part. The accumulation of the La Paja Formation took place in the supratidal to lower intertidal domain. The La Paja Formation is dated lower Barremian to middle Barremian, excluding the lowermost Barremian for segment I. The upper Barremian and lower Aptian ammonite zones are not represented. Segment II represents the upper part of the lower Aptian, while Segment III corresponds to the upper Aptian. Segment IV and the lower part of Segment V correspond to the cuspidal upper Aptian, while the rest of segment $\mathrm{V}$ corresponds to the lower lower Albian (Montoya 2019a).

The Tablazo Formation (5), a noticeable stratigraphic and geomorphologic unit, generates four cuestas and three valleys; $270 \mathrm{~m}$. The elements that form cuestas are calcareous mudstone, wackestone and packstone with minor proportions of fine to very fine quartzitic sandstone; on the contrary, the valleyforming units are predominantly made of argillaceous mudstone. The occurrence of microcodium microfossils and nodular rubble are reminders of subaerial exposure. Occasional organic matter is common at levels I to III, from which it decreases. The lower part of the unit looks transitional to the La Paja Formation. Tablazo sediments accumulated between the supratidal and middle parts of an oscillating shallow carbonate ramp. The Tablazo Formation represents the lower Albian and is an example of vertical tectonics influencing accumulation (Hubbard 1988; Montoya 2019b) (fig. 3).

The Simití Formation (6), 125 m, consists of dark, terrigenous, muscovitic and fissile mudstone (shales), interspersed throughout the unit with fine-grained, quartzitic sandstones with calcareous cement (Etayo-Serna 2019, fig. 5A), more often than not glauconitic. The accumulation of this unit started after an interlude of nondeposition and subaerial exposure of the top bed of the Tablazo Formation (fig. 2E): sea level rose possibly as an indirect consequence of the separation of Africa from South America; this way, the Tablazo ramp was rapidly inundated and at the same time received a great input of fine detrital particles from the mud discharges of a large southern river flowing E to W (Numpaque and Rolón 1998, fig. 5). Based on its ammonite content, the Simití Formation represents the lower middle Albian, pars. Exposures are poor.

The El Salto limestone (7) lies immediately above the Simití shales with a thickness of $7 \mathrm{~m}$. It is a unit not formally establis- 


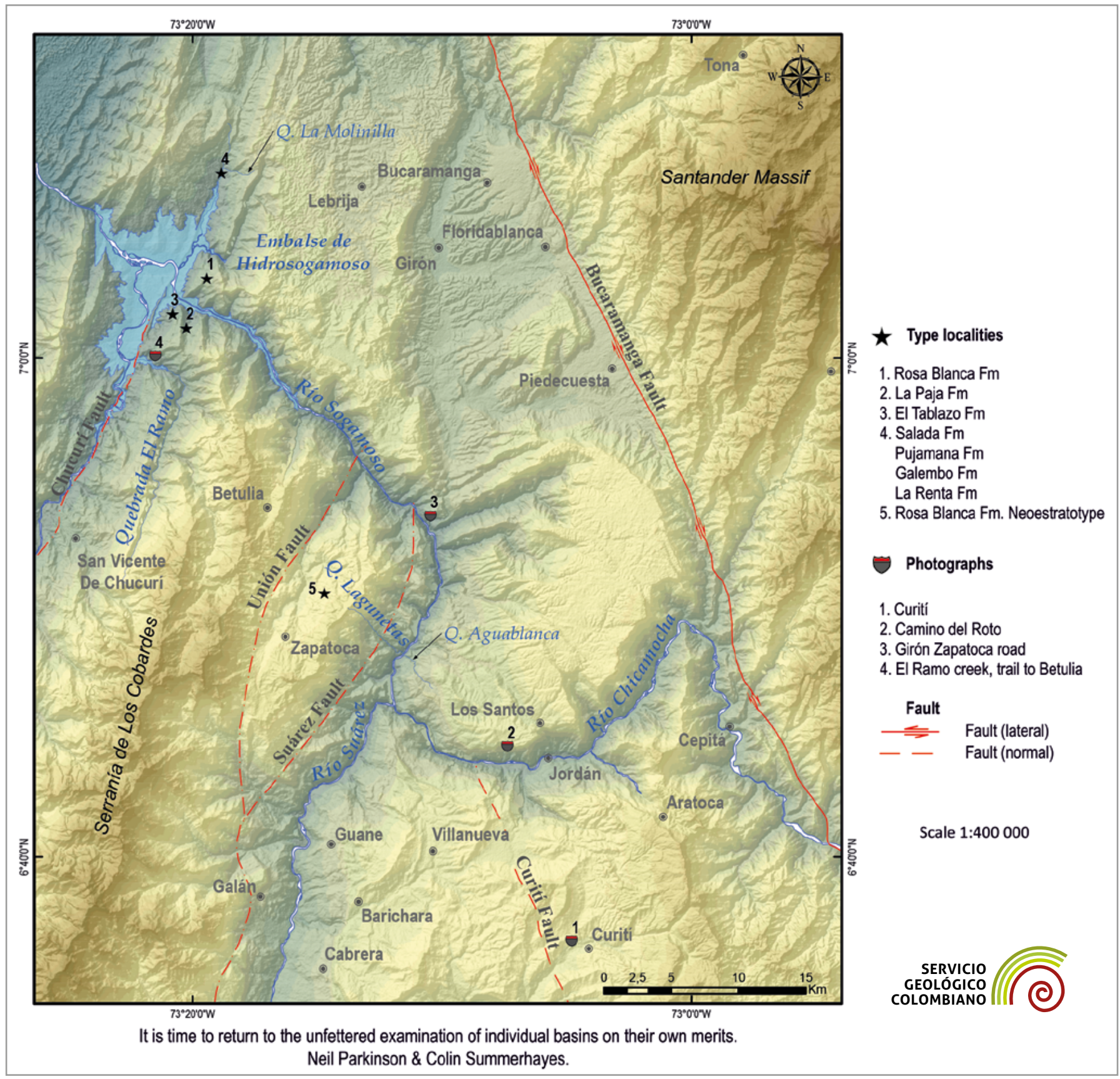

Figure 4. Map of localities mentioned in the text.

hed by Morales and The Colombian Petroleum Industry (1958) but has great significance to the geologic history of the MMV. From E to NW, Sogamoso River to Simití, the El Salto limestone-wackestone and packstone with Rhynchostreon remains-thickens from $7 \mathrm{~m}$ to $50 \mathrm{~m}$ and at the same time overlies younger beds; that is to say, its base makes a bevel in the Simití Formation illustrating a probable direct causal connection with coeval slanting to the west of the whole MMV basement (Terraza 2019).

Salada Formation (8); $118 \mathrm{~m}$. The formation status is restated for this unit. It is "composed of hard, black thin bedded, finely laminated-limy shales that appear very much as slates on outcrop [...] presence of concretions and streaks of pyrite, often mixed with limestone, and a strong bituminous odor yielded by the rock when freshly broken open" (Wheeler 1929). Large discoidal calcareous concretions in the lower segment. Benueites species of ammonites indicate a lower Turonian age (Terraza 2019).

Pujamana Formation (9); $57 \mathrm{~m}$ - $111 \mathrm{~m}$. This unit is another restated formation. "It consists of black thin bedded calcareous shale. Hills composed of this shale slump badly". Wheeler reports $325 \mathrm{~m}$ of thickness, but he himself advised "that amount might be excessive". This same section was remeasured by Terraza (2019). At this point, it is worth remembering Ernst Cloos' caveat $(1942,402):$ : [...] the question arises whether or not thicknesses as measured in folded regions are thicknesses of depo- 
sition". Specimens of the ammonites Subprionocyclus support referring this unit to the upper Turonian.

Galembo Formation (10); $96 \mathrm{~m}-177 \mathrm{~m}$. In this book, the Galembo is restated to the formation category. According to the precise original description "The Galembo is predominantly a limestone formation [...] the limestones are hard, black, (thin bedded), thinly laminated, fine textured, bituminous, occasionally shaly, and commonly occur in beds 4 to 6 inches thick separated by thin or minute shale partings. This rhythmic type of bedding is distinctly characteristic of the formation in the Sogamoso area [...] these limestones yield a distinct odor of oil when freshly broken" (Wheeler 1929). A rich ammonite collection has been gathered: Prionocycloceras, Protexanites, Miotexanites, Peroniceras (Zuluiceras) represent the Coniacian, while Texanites, Plesiotexanites and Cocuyites indicate the Santonian (see Terraza, chap. 5, this book).

La Renta Formation (11); $45 \mathrm{~m}$ - $77 \mathrm{~m}$. It has been concluded that the separation of the phosphatic and siliceous sequence-of the upper part of the Galembo-into a distinct formation is necessary. The La Renta Formation has great paleogeographic significance because during the Campanian, there were particular oceanographic conditions that favored

\section{REFERENCES}

Barrero, Darío, Andrés Pardo, Carlos A. Vargas, and Juan F. Martínez. 2007. Colombian Sedimentary Basins: Nomenclature, Boundaries and Petroleum Geology, a new Proposal. Bogotá: Agencia Nacional de Hidrocarburos.

Bürgl, Hans. 1961. "Historia geológica de Colombia". Revista de la Academia Colombiana de Ciencias Exactas, Físicas y Naturales 11 (43): 137-191.

Cáceres Girón, Carlos, Fabio Cediel Melo, and Fernando Etayo-Serna. 2003. Maps of Sedimentary Facies Distribution and Tectonic Setting of Colombia through the Proterozoic and Phanerozoic. Ingeominas: Bogotá.

Cediel, Fabio. 1968. "El Grupo Girón, una Molasa Mesozoica de la cordillera Oriental”. Boletín Geológico 16 (1-3): 5-96.

Cizancourt, Henry De. 1933. "Tectonic Structure of Northern Andes in Colombia and Venezuela". Bulletin of the American Association of Petroleum Geologists 17 (3): 211-228.

Cloos, Ernst. 1942. Distortion of stratigraphic thicknesses due to folding. Proceedings of the National Academy of Sciences 28: 401407. https://doi.org/10.1073/pnas.28.10.401.

Cooper, Mark A., Fergus T. Addison, Ricardo Álvarez, Mario Coral, Rod H. Graham, Anthony B. Hayward, Spencer Howe, Jaime Martínez, Joaquín Naar, Ricardo Peñas, Andy J. Pulham, and Adriana Taborda. 1995. "Basin development and tectonic history of the Llanos Basin, Eastern Cordillera, and Middle Magdalena Valley, Colombia”. AAPG Bulletin 79 (10): 1421-1443.

Etayo-Serna, Fernando y Georgina Guzmán-Ospitia. 2019. “Formación Rosa Blanca: subdivisión de la Formación y propuesta de Neoestratotipo. Sección laguna El Sapo, vereda El Carrizal, mu- a "South Tethyan phosphorite province" that included Colombia (Terraza 2019; Pufahl et al. 2003).

The last Cretaceous unit (12) that crops out in the Hidrosogamoso region is the Umir Formation (Morales and The Colombian Petroleum Industry 1958, 655), which lies unconformably on the La Renta or Galembo Formations 2019, in angular unconformity or in paraconformity (Maughan et al. 1979, fig. 6). The Umir, as measured along the new Bucaramanga-Barrancabermeja road, is $300 \mathrm{~m}$ thick and appears to be unconformably covered by the Lisama Formation of Paleocene palynological age. The Umir Formation consists mainly of dark to medium and light gray mudstone, light gray to greenish gray fine to medium grained muscovitic siltstone and sandstone in thin beds, increasing in thickness and abundance upsection. Interspersed cuneiform coal beds up to $1.5 \mathrm{~m}$ thick, herringbone crosslamination and oscillation ripples are conspicuous. Locally, gastropods, bivalve and ammonite remains are found (Pérez 2014). Sphenodicus pleurisepta (Conrad 1857) is relatively frequent (Morales and The Colombian Petroleum Industry 1958, 656; Moreno-Sánchez 2019). According to Petters (1955), "brackish and fresh water deposits of Maestrichtian (sic) (Navarro) age were laid down along the western margin of the Bucaramanga Massif".

nicipio de Zapatoca, departamento de Santander.". En Estudios geológicos y paleontológicos sobre el Cretácico en la región del embalse del río Sogamoso, Valle Medio del Magdalena, dirección científica y edición de Fernando Etayo-Serna. Compilación de los Estudios Geológicos Oficiales en Colombia vol. XXIII. Bogotá: Servicio Geológico Colombiano.

Etayo-Serna, Fernando, and Gloria I. Rodríguez. 1985. "Edad de la Formación Los Santos". In Proyecto Cretácico, Contribuciones, edited by Fernando Etayo-Serna and Fabio Laverde, 1-13. Publicaciones Geológicas Especiales 16. Bogotá: Ingeominas.

Etayo-Serna, Fernando, Giancarlo Renzoni, and Darío Barrero. 1976. Contornos sucesivos del mar Cretáceo en Colombia. In $\mathrm{Me-}$ morias Primer Congreso Colombiano de Geología, edited by $\mathrm{F}$. Etayo-Serna and Carlos Cáceres Girón, 217-252, Bogotá: Universidad Nacional de Colombia and Ecopetrol.

Etayo-Serna, Fernando, Nuria Solé De Porta, Jaime De Porta, and Tatiana Gaona. 2003. "The Batá Formation of Colombia is truly Cretaceous, not Jurassic". Journal of South American Earth Sciences 16: 113-117. https://doi.org/10.1016/S0895-9811(03)00048-8.

Etayo-Serna, Fernando. 1983. The Georgian heteromorph ammonite genera Kutatissites and Pseudoaustraliceras in Northwest Southamerica. Geología Norandina 7: 3-13.

Etayo-Serna, Fernando. 1989. "Análisis facial del inicio del avance marino del Cretácico en la región SW del Macizo de Santander". V Congreso Colombiano de Geología. Excursión Pre-Congreso No. 2: 1-8. Bucaramanga.

Etayo-Serna, Fernando. 1993. "Ammonitina Speciation and Eustacy". AAPG. Bulletin 77 (2): 317.

Etayo-Serna, Fernando. 2019. “'Formación' Simití: unidad ambigua en la estratigrafía del Valle Medio del Magdalena”. En Estudios 
geológicos y paleontológicos sobre el Cretácico en la región del embalse del río Sogamoso, Valle Medio del Magdalena, dirección científica y edición de Fernando Etayo-Serna. Compilación de los Estudios Geológicos Oficiales en Colombia vol. XXIII. Bogotá: Servicio Geológico Colombiano.

Fabre, Antoine. 1983. "La subsidencia de la Cuenca del Cocuy (cordillera Oriental de Colombia) durante el Cretáceo y el Terciario. Segunda parte: esquema de evolución tectónica”. Geología Norandina 8: 21-27.

Gaona-Narváez, Tatiana, Florentin J.-M.R. Maurrasse, and Fernando Etayo-Serna. 2013. “Geochemistry, palaeoenvironments and timing of Aptian organic-rich beds of the Paja Formation (Curití, Eastern Cordillera, Colombia)". In Isotopic Studies in Cretaceous Research, edited by Ana Voica Bojar, Mihaela C. Melinte-Dobrinescu and Jan Smit, 31-48. Special Publications 382. London: Geological Society. https://doi.org/10.1144/SP382.6

Gómez, Elías, Teresa E. Jordan, Richard W. Allmendiger, Kerry Hegarty, Shari Kelley, and Matthew Heizler. 2003. Controls on Architecture of the Late Cretaceous to Cenozoic Southern Middle Magdalena Valley Basin, Colombia. GSA Bulletin 115 (2): 131-147. https://doi.org/10.1130/0016-7606(2003)115<0131:COAOT$\mathrm{L}>2.0 . \mathrm{CO} ; 2$.

Harrison, John Vernon. 1930. "The Magdalena Valley, Colombia, South America”. 15th Internacional Geological Congress, South Africa, Compte Rendu, V.2, Section VI. Rift Valleys: 399-409. Pretoria.

Hubach, Enrique. 1929. "Determinación y apreciación general de las áreas petrolíferas de Colombia”. Boletín de Minas y Petróleos 1 (1): 52-62.

Hubbard, Richard J. 1988. "Age and significance of sequence boundaries on Jurassic and Early Cretaceous rifted continental margins". The American Association of Petroleum Geologists Bulletin 72 (1): 49-72.

Immenhauser, Adrian, Wolfgang Schlager, Stephen J. Burns, Robert W. Scott, Tini Geel, Jens Lehmann, Sjerry Van Der Gaast, and Liselotte J.A. Bolder-Schrijver. 2000. "Origin and correlation of disconformity surfaces and marker beds, Nahr Umr Formation, northern Oman". In Middle East Models of Jurassic/Cretaceous Carbonate Systems, 209-225. Special Publication vol. 69. Tulsa: SEPM Society for Sedimentary Geology. https://doi. org/10.2110/pec.00.69.0209.

Julivert, Manuel. 1961. "Las estructuras de valle medio del Magdalena y su significación”. Boletín de Geología 6: 33-52.

Julivert, Manuel, and Noel Téllez I. 1963. "Sobre la presencia de fallas de edad Precretácica y Post-Girón (Jura-triásico) en el Flanco W del Macizo de Santander (Cordillera Oriental, Colombia)". Boletín de Geología 12: 5-17.

Julivert, Manuel. 1970. "Cover and Basement Tectonics in the Cordillera Oriental of Colombia, South America, and a Comparison with some Other Folded Chains". Geological Society of America Bulletin 81 (12): 3623-3646. https://doi. org/10.1130/0016-7606(1970)81[3623:CABTIT]2.0.C0;2.

Luyendyk, Bruce Peter, Donald Forsyth, and Joseph D. Phillips. 1972. "Experimental Approach to the Paleocirculation of the Oceanic Surface Waters". Geological Society of America Bulletin 83 (9): 2649-2664. https://doi.org/10.1130/00167606(1972)83[2649:EATTP0]2.0.C0;2.

Maughan, Edwin K., Francisco Zambrano 0., Pedro Mojica G., Jacob Abozaglo M., Fernando Pachón P., and Raúl Durán R. 1979. "Paleontologic and Stratigraphic relations of Phosphate Beds in Upper Cretaceous Rocks of the Cordillera Oriental, Colombia". USGS report. Open File Report 79-1525. https://doi. org/10.3133/ofr791525.
Morales, Luis G., and The Colombian Petroleum Industry. 1958. "General geology and oil occurrences of Middle Magdalena Valley, Colombia". In Habitat of oil. A symposium; conducted by the American Association of Petroleum Geologists, edited by Lewis G. Weeks, 641-695. Special Publication 18. Tulsa: The American Association of Petroleum Geologists.

Moreno-Sánchez, Giovanni. 2019. "Mapa geológico del Valle Medio del Magdalena en los alrededores del puente El Tablazo, departamento de Santander". En Estudios geológicos y paleontológicos sobre el Cretácico en la región del embalse del río Sogamoso, Valle Medio del Magdalena, dirección científica y edición de Fernando Etayo-Serna. Compilación de los Estudios Geológicos Oficiales en Colombia vol. XXIII. Bogotá: Servicio Geológico Colombiano.

Numpaque, Luis, and Luisa Fernanda Rolón. 1998. "Formación Areniscas de Chiquinquirá: características sedimentológicas y alternativas de nuevas oportunidades de roca almacenadora en la exploración de hidrocarburos en las cuencas Cordillera Oriental y SE de Valle Medio del Magdalena". XXX Conferencia Geológica de Campo 1997-1998. Asociación Colombiana de Geólogos y Geofísicos del Petróleo.

Orbigny, Alcide Dessalines De. 1842. Coquilles et échinodermes fossiles de Colombie (Nouvelle-Grenade), recueillis de 1821 a 1833, par M. Boussingault, et décrits par Alcide d'Orbigny. Paris: P. Bertrand Paris \& Strasbourg.

Parkinson, Neil, and Colin Summerhayes. 1985. "Synchronous Global Sequence Boundaries". The American Association of Petroleum Geologists Bulletin 63 (5): 685-687.

Pérez Ávila, Adrián. 2014. "Estratigrafía Formación Umir". Bogotá: Servicio Geológico Colombiano.

Petters, Victor. 1955. "Development of Upper Cretaceous Foraminiferal Faunas in Colombia". Journal of Paleontology 29 (2): 212225.

Pufahl, Peir K., Kurt A. Grimm, Abdulkader M. Abed, and Rushdi M.Y.Saqah. 2003. "Upper Cretaceous (Campanian) phosphorites in Jordan: implications for the formation of a South Tethyan Phosphorite giant". Sedimentary Geology 161 (3-4): 175-205. https://doi.org/10.1016/S0037-0738(03)00070-8.

Ravnås, Rodmar, and Ron J. Steel. 1998. "Architecture of Marine Rift-Basin Successions". APPG Bulletin 82 (1): 110-146.

Rawson, Peter F. 1993. "The influence of sea-level changes on the migration and evolution of early Cretaceous (pre-Aptian) ammonites". In The Ammonoidea: Environment, Ecology, and Evolutionary Change, edited by M. R. House, 227-242. Systematics Association. Special volume 47. 0xford: Clarendon Press.

Rolón, Luisa Fernanda. 2004. "Structural Geometry of the Jura-Cretaceous Rift of the Middle Magdalena Valley Basin-Colombia". Master thesis of Sciences in Geology. West Virginia University.

Rolón, Luisa Fernanda, and Milton Carrero Melo. 1995. “Análisis estratigráfico de la sección cretácica aflorante al oriente del anticlinal de los Cobardes entre los Municipios de Guadalupe-Chima-Contratación, Dpto. de Santander". Trabajo de pregrado. Universidad Nacional de Colombia.

Rolón, Luisa Fernanda, Juan Lorenzo, Allan Lowrie, and Darío Barrero. 2001. "Thrust, kinematics and Hydrocarbon migration in the Middle Magdalena Basin, Colombia, South America". GCSSEPM Foundation 21st Annual Research Conference Petroleum Systems of Deep- Water Basins. Houston.

Rolón Luisa, and Jaime Toro. 2003. "Abstract: Extensional Structures Related to the Jurassic-Cretaceous Rift of the Middle Magdalena Valley Basin-Colombia”. AAPG Bulletin 87 (13. Supplement). 
Sarmiento-Rojas, Luis Fernando. 2001. "Mesozoic rifting and Cenozoic basin inversion history of the Eastern Cordillera, Colombian Andes. Inferences from tectonic models". Ph. D. Thesis. Vrije Universiteit.

Schuchert, Charles. 1935. "Colombia”. In Historical Geology of the Antillean-Caribbean Region or the Lands Bordering the Gulf of Mexico and the Caribbean Sea, 624-674. New York: John Wiley \& Sons, Inc. Spanish Translation 1937, in Boletín de Petróleos 97-102: 265-354.

Stille, Hans. 1938. Estudios geológicos en la región del río Magdalena. Compilación de los Estudios Geológicos Oficiales en Colombia 4: 125-182. Traducción de Geologische Studien im Gebiete des Río Magdalena. Festschrift Adolf von Koenen: 277-358, Stuttgart 1907.

Terraza Melo, Roberto. 2019. “'Formación La Luna': expresión espuria en la geología colombiana”. En Estudios geológicos y paleontológicos sobre el Cretácico en la región del embalse del río Sogamoso, Valle Medio del Magdalena, dirección científica y edición de Fernando Etayo-Serna. Compilación de los Estudios
Geológicos Oficiales en Colombia vol. XXIII. Bogotá: Servicio Geológico Colombiano.

Toro, Jaime, François Roure, Sophie Lecornec-Lance, Nathalie Bordas-Lefloch, and William Sassi. 2002. "Structural and Thermal Evolution of the Cordillera Oriental, Colombia". AAPG Hedberg Conference "Deformation History, Fluid flow Reconstruction, and Reservoir Appraisal in Foreland Fold and Thrust Belts". May 14-18. Palermo-Mondello (Sicily-Italy).

Wheeler, Orby Clinton. 1929. Report on the Palmira Series with Notes on Stratigraphy of the Umir, Lisama, and La Paz Formations Near the Eastern Part of the Mares Concession. Informe Geológico 37. Bogotá: Ecopetrol.

Willis, Bailey. 1928. Dead Sea problem: rift valley or ramp valley? Bulletin of the Geological Society of America 39: 490-542.

Wilson, J. Tuzo. 1990. "Some Controls that Greatly Affect Surface Responses to Mantle Convection Beneath Continents". In The Restless Earth, edited by Keith J. Carlson, 125-162. Nobel Conference XXIV. Chapter 5. San Francisco: Harper \& Row. 